\title{
EXPLORING THE EFFECT OF CORPORATE SOCIAL RESPONSIBILITY, LEVERAGE, AND INTELLECTUAL CAPITAL ON FINANCIAL PERFORMANCE (EMPIRICAL EVIDENCE FROM BANKING SECTOR COMPANIES PERIOD 2015-2019)
}

\author{
Bambang Subiyanto ${ }^{1}$, Dipa Teruna Awaludin ${ }^{2}$, Ramang H. Demolingo ${ }^{3}$, Risca Ifani ${ }^{4}$, Kadek Wiweka ${ }^{5 *}$ \\ ${ }^{1,2,3,4}$ Lecturer, Fakultas Ekonomi dan Bisnis Universitas Nasional, Indonesia; ${ }^{5 *}$ Doctoral Student, École Doctorale \\ Sociétés, Temps, Territoires (EDSTT) Tourisme, Université Angers, France and Sahid Polytechnic, Indonesia. \\ Email: ${ }^{1}$ bambang.subiyanto@ civitas.unas.ac.id, ${ }^{2}$ dipateruna@ civitas.unas.ac.id, ${ }^{3}$ ramang.demolingo@civitas.unas.ac.id, \\ ${ }^{4}$ risca.ifani26@gmail.com, ${ }^{5 *}$ kadek.wiweka@etud.univ-angers.fr \\ Article History: Received on $24^{\text {th }}$ June 2021, Revised on $8^{\text {th }}$ July 2021, Published on $10^{\text {th }}$ July 2021
}

\begin{abstract}
Purpose of the Study: This study aims to analyze the effect of independent variables such as corporate social responsibility, leverage, and intellectual capital on dependent variables such as financial performance in banking sector companies indexed on the Indonesia Stock Exchange in 2015-2019.

Methodology: This review is adopted the descriptive statistics approach. While the hypothesis test using multiple linear regression analysis and simultaneous significance analysis. Secondary data collected through the purposive sampling method consisted of 85 samples from 17 companies.

Main Findings: The results indicate that CSR has a positive effect on FP. While LEV and IC have no effect on FP. Debt withdrawal will not have an impact on the company's sustainability in increasing profits. In addition, the company also has a concern for the disclosure of CSR activities through the GRI, which can increase the company's profit.

Implication/Applications: The results of this study can be used for financial practitioners, especially in the banking industry, to determine the effect of corporate social responsibility, leverage, and intellectual capital on financial performance. Therefore, banking companies can make decisions based on the priority scale on the most influential variables. In addition, this research can also be a reference for academics and researchers who are interested in the issue of financial performance.
\end{abstract}

The originality of the study: The results of this study are the latest studies that systematically and comprehensively discuss the financial performance of the banking sector based on several important factors.

Keywords: Corporate Social Responsibility, Leverage, Intellectual Capital, Financial Performance, Banking Companies.

\section{INTRODUCTION}

The company's financial performance is a reflection of the financial situation or condition of a company in a certain period. Performance can be defined as a measurable activity of an entity in a certain period as part of the success of the work. Information about a company's performance can be used, one of them as a report of interest, to design further policies that will be adopted by management (Chen \& Wang, 2011; Magness, 2006; Mojambo et al., 2020; Moneva et al., 2007). Therefore, the company's performance is essential to measure and analyze its progress every year.

Financial statements have a lot of important information that can be used to see the development of the company's performance. While Maith 2013 notes that financial performance is the achievements, records, and past information that can be seen through the company's financial statements. This report also provides some required information regarding performance, such as financial position and cash flow in a certain period. Financial ratio analysis in the company's financial reports can provide an illustration of how high and good the company's performance level is.

The Indonesian Institute of Accountants states that company performance is measured by analyzing and evaluating financial statements (Elena, 2012; Rabuisa et al., 2018). Information on the financial position and past financial performance is often used to predict financial position to measure future performance. This information is also useful for determining dividend payments, wages, security price movements, and the company's ability to meet its commitments when they fall due. Therefore, the company's performance must be measured and monitored regularly for every year's progress.

The company's efforts to improve performance through performance measurement and the factors that can improve company performance are very important for companies to know. In addition, this performance should also be known transparently by interested parties, including decision-makers. (Sarwoko \& Agoes, 2014) in their research state that fraudulent financial reporting practices are a phenomenon that cannot be ignored in current audits. Common frauds include manipulation of sales management, failure to record accounts payable, delays in write-offs, and deliberately false financial reports. Meanwhile, (Subiyanto \& Ghozali, 2021) noted that the difference between the excess and the 
understatement in the financial statements at the time of actual realization will have an impact on future cash flows and will automatically affect profit.

Research by (Staniewski et al., 2016; Strömsten \& Waluszewski, 2012) states that the scarcity of external financing can cause the company's technological backwardness. They are therefore unable to invest in the necessary resources to develop and ensure profitability. Financial motives often underlie decisions to use their sources of funds or loans that must be repaid in the future. Suppose a company chooses an external funding source, namely in the form of debt. In that case, several things must be considered in the use of debt, including (i) the lender will focus on the amount of collateral for the credit granted; (ii) the company must earn more than the expenses, as evidence that the company will increase; (iii) by using debt, the owner can obtain funds so as not to lose control of the company.

Several studies on similar topics also conclude some of the arguments. Literatures show that corporate social responsibility positively affects the company's financial performance (Lin et al., 2009; Tsoutsoura, 2004; Turcsanyi \& Sisaye, 2013). Meanwhile, research conducted by (Fuadah et al., 2019; Mustafa \& Handayani, 2014; Natalylova, 2013) shows that CSR does not affect company performance. Meanwhile, Nopitasari et al., 2017 prove that leverage has an effect on the company's financial performance. On the other hand, research conducted by Afolabi et al., 2019 and Rehman, 2013 found that the leverage variable has a negative effect on financial performance. Bollen et al., 2005 and Janošević et al., 2013) researched intellectual capital, which states that there is no positive influence between its intellectual capital and performance. On the other hand, research by (Joshi et al., 2013; Kianto et al., 2013; Susanti et al., 2020; Zeghal \& Maaloul, 2010) proves that Intellectual Capital (IC) has a positive effect on the company's financial performance.

These references show that the supporting factors of financial performance such as CSR, leverage, and intellectual capital have different impacts on various types of companies. However, these factors have been shown to have a role both directly and indirectly. Therefore, this study is interested in testing some of these findings on the performance of banking companies. This case study was selected based on its essential role and function, especially with regard to improving and distributing the welfare and economy of the community. This supporting factor is also still very rarely studied from the point of view of banking financial performance. Therefore, this study focuses on the issue of whether these three factors affect the financial performance of banking companies.

Based on this background, research related to the issue of the influence of Corporate Social Responsibility, Leverage, and Intellectual Capital on Financial Performance needs to be done. Specifically, this study uses case studies on the banking sector registered on the Indonesia Stock Exchange, period 2015 to 2019. The researcher aims to prove the hypothesis designed from the results of previous studies. In particular, this study designed three research objectives: analyzing the effect of corporate social responsibility on financial performance. Second, reviewing the effect of leverage on financial performance. Finally, proving the influence of intellectual capital on financial performance. This research can be practically useful for banking performers, especially to see the effect of the variables used in this study on the company's financial performance.

\section{LITERATURE REVIEW}

\section{Agency Theory}

(Jensen \& Meckling, 1976) assume, based on agency theory as a grand theory, that individuals will act in their own interests. The agency relationship arises because of a contract between the company's management (agent) and shareholders (principal). The owner authorizes the company's management to carry out the company's operations, including in the decision-making section. (Subiyanto \& Ghozali, 2021) argue that management has an interest in maintaining its position or maximizing the compensation received from the company.

\section{Resources Based Theory}

This theory is basically a supporting theory that explains the use of resources owned by the company's ability to utilize and manage company resources properly. As a result, the company can gain a competitive advantage on an ongoing basis. (Schuler \& Jackson, 1987) explain that there are three types of resources: physical resources in the form of equipment, factory, geographical location, and technology. The second is human resources in the form of employee knowledge and experience. Last but not least is organizational resources in the form of control, structure, supervisory system, and social relations between organizations and the external environment.

Furthermore, as another supporting theory, legitimacy theory states that through legitimacy theory, organizations or companies continue to strive to ensure that the activities they carry out are in accordance with the frames and norms that exist in society or the environment. In addition, they also ensure that the activities carried out can be legally accepted by outsiders (Deegan, 2014).

\section{Financial performance}

The Indonesian Institute of Accountants argues that financial performance is the company's ability to manage and control its resources (Oktafianti, 2015). He added that company performance could be measured by analyzing and 
evaluating financial statements (Safira \& Riduwan, 2015). Information on the past financial position and financial performance is often used as a basis for predicting future financial position and performance. In addition, this information is also used to consider users of dividends, wages, security price movements, and the company's ability to meet its commitments.

\section{Corporate Social Responsibility (CSR)}

Elkington's research (Elkington, 2013) suggests that the company will pay attention to three aspects, namely improving the quality of the company (profit), attention to the community, especially the surrounding community (people), and the environment (planet earth) as a form of corporate social responsibility. CSR is one of the important concepts in corporate management. In general, it can be pointed out that the highlight of CSR is on the integration of voluntary consideration to social and environmental problems into business behavior to react to social problems (Gray, 2010).

Based on these arguments, the study proposes the following hypothesis:

$\mathbf{H}_{\mathbf{1}}$ : Corporate social responsibility has a positive effect on financial performance.

\section{Leverage}

Leverage is the use of fixed assets or sources of funds where for the use of these funds, the company must bear fixed costs or pay fixed expenses to increase the level of income for the owner of the company. The use of assets that incur a fixed burden is called operating leverage, while the use of funds with a fixed load is called financial leverage (Sudana, 2011). Kasmir states that leverage is a calculation of financial ratios used to measure the extent to which the company's asset activities are financed with debt (Erica, 2018; Rizal, 2017). The greater the debt used by the company, the higher the level of financial leverage (Tedjo, n.d.).

Based on this discussion, the following hypothesis is proposed:

$\mathbf{H}_{2}$ : Leverage has a positive effect on financial performance.

\section{Intellectual Capital}

Research by (Muna \& Prastiwi, 2014) concludes that intellectual capital is a resource owned by a company in the form of knowledge and intangible assets that can be used as added value for companies to create innovation and competitive business competition. According to (Xu \& Liu, 2020), intellectual capital (IC) is widely recognized as an essential conductor of value-enhancing firms' competitiveness in the knowledge economy. Meanwhile, according to (Calza et al., 2014) and (Chowdhury et al., 2019) states that intellectual capital is not only an important driver and asset in the value creation and sustainable development of the company. It is also a source of invention and a fundamental to profit growth. In addition, (Laksana \& Sudarno, 2013) states that the concept of intellectual capital refers to resources in the form of knowledge, experience, and technology available to the company.

Based on this argument, the following hypothesis is proposed:

$\mathrm{H}_{3}$ : Intellectual capital has a positive effect on financial performance.

\section{RESEARCH MODEL}

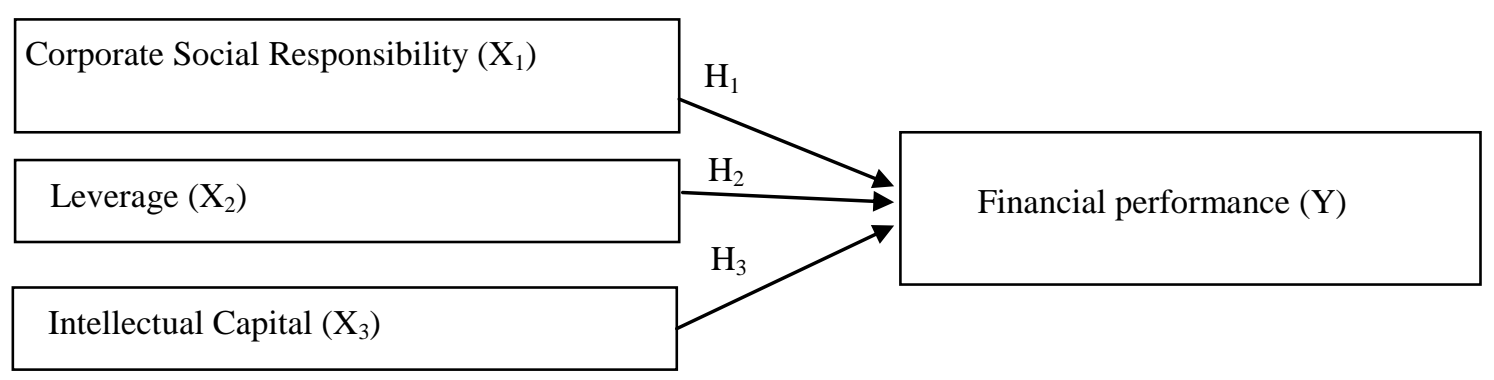

Figure 1: Analysis Framework

Source: Authors

Description:

$\mathrm{X}_{1}=$ Corporate Social Responsibility

$\mathrm{X}_{2}=$ Leverage

$\mathrm{X}_{3}=$ Intellectual Capital

$\mathrm{e}=$ Error

$\mathrm{H}_{1}=$ Corporate social responsibility has a positive effect on financial performance. 
$\mathrm{H}_{2}=$ Leverage has a positive effect on financial performance.

$\mathrm{H}_{3}=$ Intellectual capital has a positive effect on financial performance.

\section{METHODOLOGY}

The approach adopted in this study is descriptive statistics (Sugiyono, 2016). While the hypothesis test using multiple linear regression analysis and simultaneous significance analysis. Multiple linear regression data analysis was used because this study used more than one independent variable and only one dependent variable (Ghozali, 2011). This analysis is used to examine the effect of corporate social responsibility, leverage, and intellectual capital simultaneously on financial performance with the following equation:

\section{$\mathbf{F P}=\alpha+\beta 1 \mathrm{CSR}+\beta 2 \mathrm{LEV}+\beta 3 \mathrm{IC}+\mathrm{e}$}

Description:

$\mathrm{FP}=$ Financial performance

$\alpha=$ Constant

$\beta=$ Variable Regression Coefficient

CSR $=$ Corporate Social Responsibility

$\mathrm{LEV}=$ Leverage

IC = Intellectual Capital

$\mathrm{e}=$ Error

The study was conducted in a banking company listed on the Indonesia Stock Exchange (IDX) for five years, starting from 2015-2019. While the secondary data used in this study are the annual financial reports published by the Indonesia Stock Exchange (IDX) and the websites of each sample company.

Table 1: Sample Selection Procedure

\begin{tabular}{llll}
\hline No. & Sample Selection Procedure & Total \\
\hline 1. & Companies indexed on the Indonesia Stock Exchange for the period 2015-2019 & 225 \\
\hline 2. & Companies delisted on the Indonesia Stock Exchange for the 2015-2019 period & $(50)$ \\
\hline 3. & Lates listing company and suffered a loss on the IDX for the 2015-2019 period. & (75) \\
\hline 4. & The company has no audited annual report period 2015-2019 & $(15)$ \\
\hline $\mathbf{5 .}$ & The number of samples used for the 2015-2019 period & $\mathbf{8 5}$ \\
\hline
\end{tabular}

Source: The author's own study, 2021

Based on the above criteria, the sample used in this study was 17 companies that could be used in 5 -year Financial Performance research in the 2015-2019 annual report.

Table 2: Research Sample

\begin{tabular}{llll}
\hline No. & Company name & Issuer Code & Registration Date on IDX \\
\hline 1. & Bank Negara Indonesia (Persero) Tbk & BBNI & 25 November 1996 \\
\hline 2. & Bank Rakyat Indonesia (Persero) Tbk & BBRI & 10 November 2003 \\
\hline 3. & Bank Tabungan Negara (Persero) Tbk & BBTN & 17 Desember 2009 \\
\hline 4. & Bank Danamon Indonesia Tbk & BDMN & 06 Desember 1989 \\
\hline 5. & Bank Ina Perdana Tbk & BINA & 16 Januari 2014 \\
\hline 6. & Bank Pembangunan Daerah Jawa Barat Tbk & BJBR & 08 Juli 2010 \\
\hline 7. & Bank Pembangunan Daerah Jawa Timur Tbk & BJTM & 12 Juli 2012 \\
\hline 8. & Bank Maspion Indonesia Tbk & BMAS & 11 Juli 2013 \\
\hline 9. & Bank Mandiri (Persero) Tbk & BMRI & 14 Juli 2003 \\
\hline 10. & Bank Bumi Arta Tbk & BNBA & 01 Juni 2006 \\
\hline 11. & Bank CIMB Niaga Tbk & BNGA & 29 Nopember 1989 \\
\hline 12. & Bank Maybank Indonesia Tbk & BNII & 21 Nopember 1989 \\
\hline 13. & Bank Tabungan Pensiunan Nasional Tbk & BTPN & 12 Maret 2008 \\
\hline 14. & Bank China Construction Bank Indonesia Tbk & MCOR & 03 Juli 2007 \\
\hline 15. & Bank OCBC NISP Tbk & NISP & 20 Oktober 1994 \\
\hline 16. & Bank Nationalnobu Tbk & NOBU & 20 Mei 2013 \\
\hline 17. & Bank Woori Saudara Indonesia 1906 Tbk & SDRA & 15 December 2006 \\
\hline
\end{tabular}

Source: The author's own study, 2021 


\section{Variable Operational and Measurement}

Table 3: Variable Operational Definition

\begin{tabular}{|c|c|c|c|}
\hline Variable & Variable Concept & Measurement & References \\
\hline $\begin{array}{l}\text { Corporate } \\
\text { Social } \\
\text { Responsibility } \\
\left(\mathrm{X}_{1}\right)\end{array}$ & $\begin{array}{l}\text { The calculation of the CSDI index } \\
\text { is conducted by a dichotomous } \\
\text { approach where each CSR item in } \\
\text { the research instrument disclosed } \\
\text { by the company is given a value of } \\
1 \text { and a value of } 0 \text { if it is not } \\
\text { disclosed. }\end{array}$ & $\begin{array}{l}\text { CSRDI }=\frac{\Sigma x i f}{79} \\
0=\text { not disclosed } \\
1=\text { disclosed }\end{array}$ & $\begin{array}{l}\text { (Sayekti \& Wondabio, } \\
\underline{2007)}\end{array}$ \\
\hline Leverage $\left(\mathrm{X}_{2}\right)$ & $\begin{array}{l}\text { Solvency or Leverage is a ratio } \\
\text { used to evaluate the extent to } \\
\text { which company assets are } \\
\text { financed by debt. }\end{array}$ & $\begin{array}{l}\text { Debt Ratio }(\mathrm{DR}) \\
\frac{\text { Total Debt }}{\text { Total Assets }} \times 100 \%\end{array}$ & $\begin{array}{l}\text { (Rachmanda et al. } \\
\underline{2016)}\end{array}$ \\
\hline
\end{tabular}

\begin{tabular}{|c|c|c|c|}
\hline $\begin{array}{l}\text { Intellectual } \\
\text { Capital }\left(\mathrm{X}_{3}\right)\end{array}$ & $\begin{array}{l}\text { Intellectual capital in this study is } \\
\text { determined based on the value- } \\
\text { added model, which is proxied } \\
\text { from physical capital (VACA), } \\
\text { human capital (VAHU), and } \\
\text { structural capital (STVA). The } \\
\text { combination of the three value- } \\
\text { added is symbolized by the name } \\
\text { VAICTM. }\end{array}$ & $\begin{array}{l}\text { VAICTM } \\
\text { VACA+VAHU+ STVA } \\
\text { Where: } \\
\text { VAICTM = Value-added } \\
\text { intellectual capital } \\
\text { VACA = Value-added } \\
\text { capital coefficient } \\
\text { VAHU = Value-added } \\
\text { human capital } \\
\text { STVA = Value-added } \\
\text { structural capital }\end{array}$ & (Sunarsih, 2012) \\
\hline $\begin{array}{l}\text { Financial } \\
\text { performance } \\
(\mathrm{Y})\end{array}$ & $\begin{array}{l}\text { Financial performance is defined } \\
\text { as determining the size of a } \\
\text { company's success in generating } \\
\text { profits. In general, the relationship } \\
\text { between companies' level of } \\
\text { information disclosure and the } \\
\text { company's market performance is } \\
\text { still very diverse. Theoretically, } \\
\text { there is a positive relationship } \\
\text { between disclosure (including } \\
\text { voluntary disclosure) and the } \\
\text { firm's market performance. }\end{array}$ & $\begin{array}{l}\text { Return on Assets (ROA) } \\
= \\
\frac{\text { Profit before Interest and }}{\text { Total Assets }}\end{array}$ & $\begin{array}{l}\text { (Sayekti \& Wondabio, } \\
\text { 2007) }\end{array}$ \\
\hline
\end{tabular}

Source: The author's own study, 2021

\section{RESULT AND DISCUSSION}

The population involved in this review were all banking companies indexed on the Indonesia Stock Exchange, period 2015-2019. While the method of sample determination used is purposive sampling, namely selecting samples based on predetermined criteria.

The research sample data shows the static development of financial performance and the fluctuating development of Corporate Social Responsibility (CSR) in banking companies.

The statistical results (Figure 2) of the t-test show that the corporate social responsibility variable has a significant positive effect on financial performance. The calculation refers to the company's fluctuating performance results. This illustrates that CSR, which has decreased, will not necessarily reduce financial performance. Likewise, when CSR produces a good response from the community, it is possible that an increase can occur, impacting the company's financial performance.

The statistical results (Figure 3) of the t-test show that the intellectual capital variable has a negative and insignificant effect on financial performance. The calculation refers to the results of the average rise and fall of the company's performance. This means that the increase in company profits is not only caused by the company's operating costs. However, there is also the influence of the company's intellectual capital despite the lack of achievement in 
implementing Intellectual Capital properly. Meanwhile, when the company's profit decreases, the value of the company's Intellectual Capital also decreases.

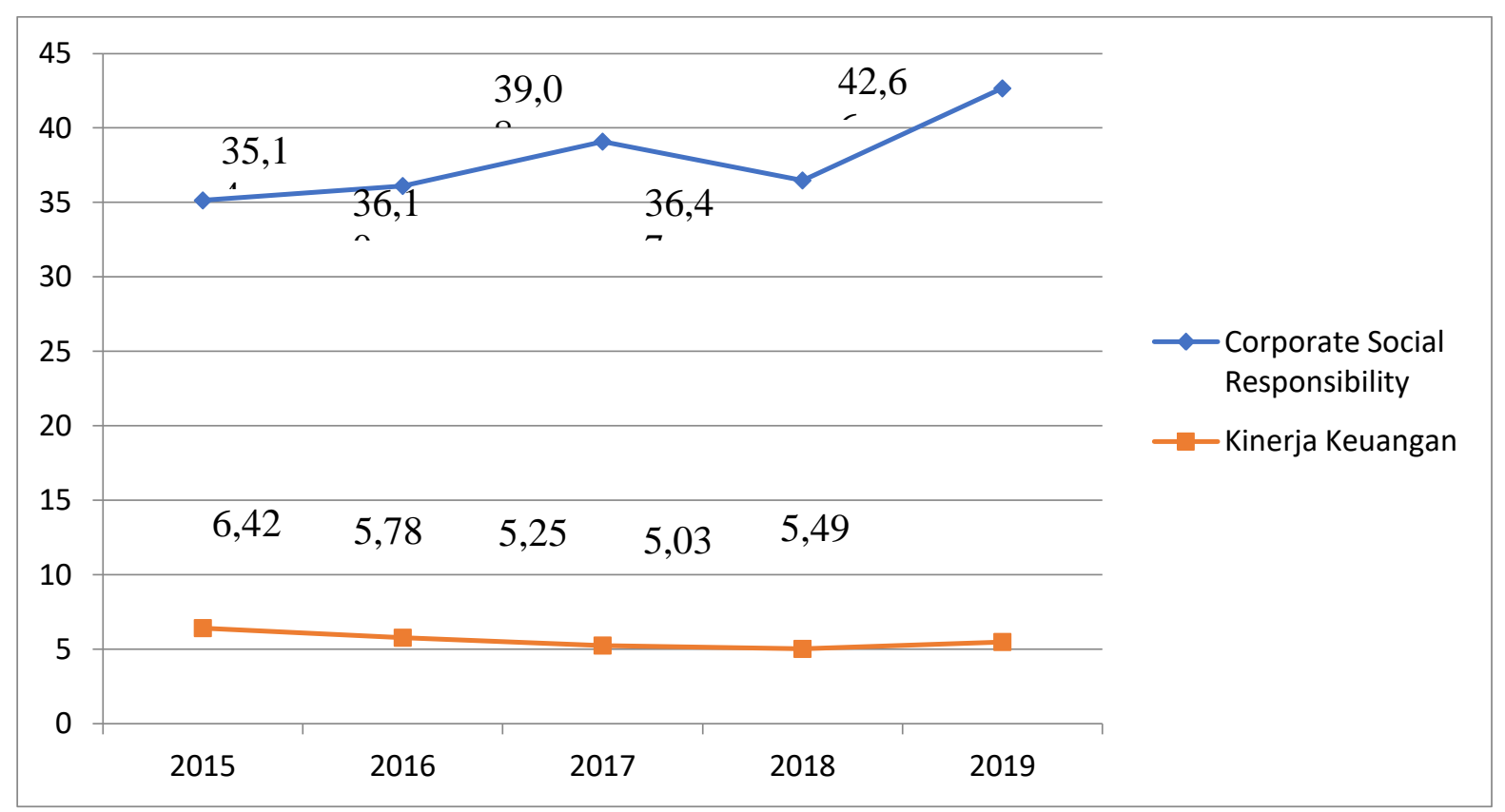

Figure 2: Average Value of Corporate Social Responsibility (CSR) and Financial Performance

Source: Author's own study, 2020

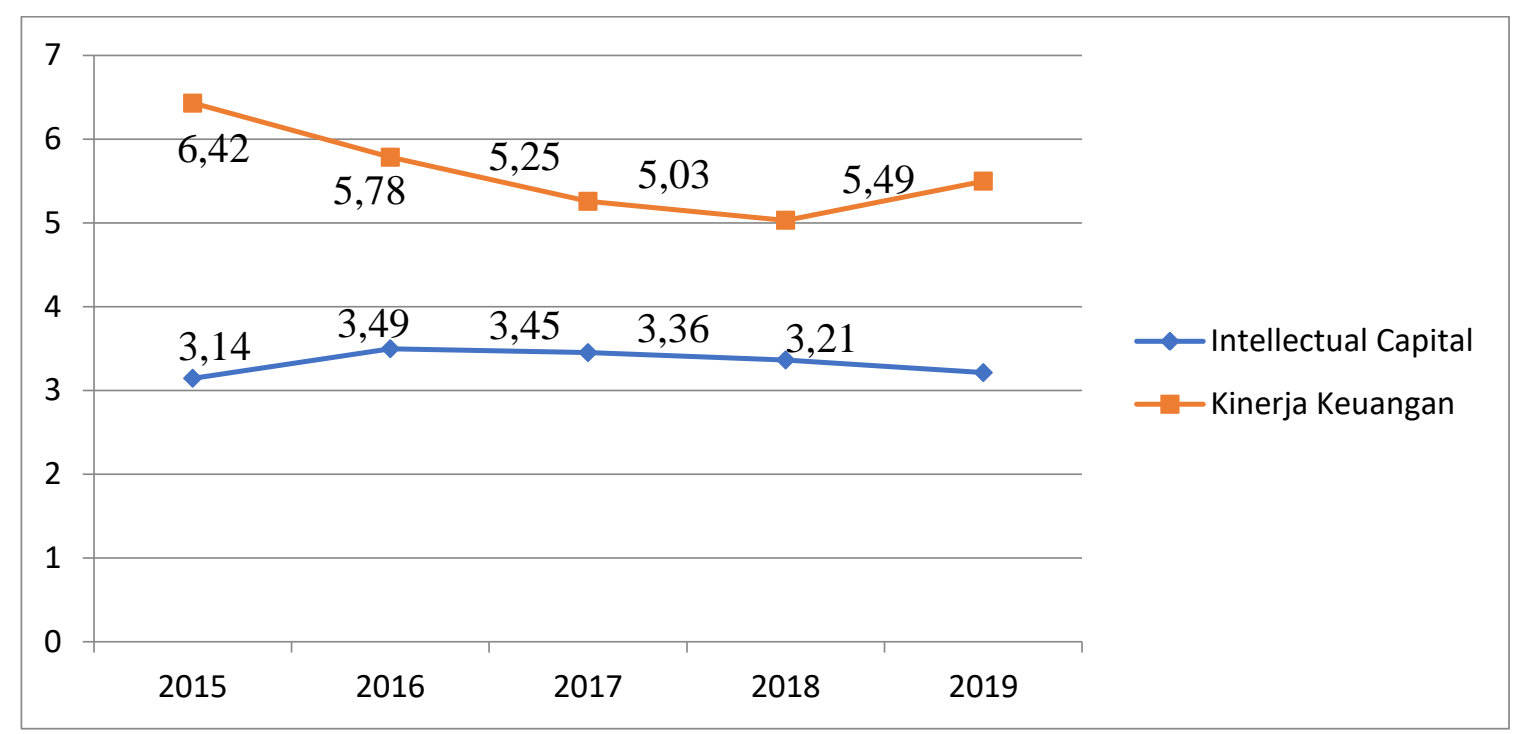

Figure 3: Average Value of Intellectual Capital and Financial Performance

Source: The author's own study, 2021

\section{Descriptive statistics}

Table 4: Descriptive statistic result $(\mathrm{n}=85)$

\begin{tabular}{lllll}
\hline Variable & Minimum & Maximum & Mean & Std. Deviation \\
\hline Financial Performance & 2.79 & 9.55 & 5.5991 & 1.21809 \\
\hline CSR & 11.39 & 69.62 & 37.8949 & 14.90473 \\
\hline Leverage & 61.44 & 91.93 & 82.7865 & 4.66802 \\
\hline Intellectual Capital & 1.32 & 5.19 & 3.3334 & 1.02600 \\
\hline
\end{tabular}

Source: The author's own study, 2020

\section{Normality test}

Asymp Value. Sig. (2-tailed) shows that the significant value of the Komogolov-Smirov test is 0.200, which is greater than the significance level of 0.05 . This means that the residual power has been normally distributed. 


\section{Multicollinearity test}

The statistical test shows that the tolerance score is higher than 0.1. Meanwhile, the VIF value is less than 10. Therefore, it can be terminated that Corporate Social Responsibility, Leverage, and Intellectual Capital are free from multicollinearity problems, which means that there is no correlation between the independent variables.

\section{Heteroscedasticity test}

The diagram shows that the distribution of dots above and below zero on the $\mathrm{Y}$-axis indicates that there is no clear pattern. Therefore, it can be concluded that there is no heteroscedasticity in the regression model.

\section{Multiple linear regression analysis}

The results of the multiple linear regression tests found the following regression equation model.

$\mathrm{FP}=6.889+0.024 \mathrm{CSR}-0.012 \mathrm{LEV}-0.362 \mathrm{IC}+\mathrm{e}$

The interpretation of the multiple linear regression equation above is as follows:

$\alpha=$ value of 6.889 indicates that if the independent variable value is 0 , then the amount of Financial Performance (FP) is positive at 6.889 .

CSR = positive regression coefficient means that there is a positive relationship between CSR and Financial Performance. In other words, the higher the CSR, the higher the financial performance.

LEV = regression coefficient is negative, meaning that there is a negative relationship between Leverage and Financial Performance. In other words, the higher the leverage, the lower the financial performance.

IC = regression coefficient is negative, meaning that there is a negative relationship between Intellectual Capital and Financial Performance. In other words, the higher the Intellectual Capital, the lower the Financial Performance.

\section{Hypothesis testing}

\section{Model Feasibility Test (F-test)}

Statistics show that the F-count value is 3.034 , with a significance indicating 0.034 . This means that the significance value is smaller than $\alpha=0.05$. This concludes that simultaneously Financial Performance is influenced by Corporate Social Responsibility (CSR), Leverage, and Intellectual Capital.

\section{Coefficient of Determination $\left(\mathbf{R}^{2}\right)$}

The variables of Corporate Social Responsibility (CSR), Leverage, and Intellectual Capital have an influence on Financial Performance by $68 \%$, while the remaining $32 \%$ is explained by other factors not explained by this study.

\section{Partial Test (t-test)}

Table 5: t-Statistical Test Results (Partial Test)

\begin{tabular}{llll}
\hline & \multicolumn{1}{c}{ Variable } & T & Sig. \\
\hline 1 & & & \\
\cline { 2 - 4 } & Constant & 3.020 & 0.003 \\
\cline { 2 - 4 } & CSR & 2.484 & 0.015 \\
\cline { 2 - 4 } & Leverage & -0.428 & 0.670 \\
\cline { 2 - 4 } & Intellectual Capital & -2.525 & 0.140 \\
\hline
\end{tabular}

Source: The author's own study, 2021

The table above shows that the Corporate Social Responsibility (CSR) variable has a regression coefficient of $t_{\text {count }}$ $(2.484)<\mathrm{t}_{\text {table }}(1.989)$ with a significance level of 0.015 less than $5 \%$ or $(0.015)<\alpha(0.05)$. The test results show that $\mathrm{H}_{0}$ is rejected and $\mathrm{H}_{1}$ is accepted. Therefore, it can be concluded that Corporate Social Responsibility (CSR) has a significant positive effect on Financial Performance (Awaysheh et al., 2020; Javed et al., 2020; Liu et al., 2021; Partalidou et al., 2020).

The test results on the Leverage variable have a regression coefficient of $\mathrm{t}_{\text {count }}(-0.428)<\mathrm{t}_{\text {table }}(1.989)$ with a significance level of 0.670 greater than $5 \%$ or $(0.670)>\alpha(0.05)$. The test results indicate that $\mathrm{H}_{0}$ is accepted and $\mathrm{H}_{1}$ is rejected. In other words, it can be concluded that Leverage has a negative and insignificant effect on Financial Performance (Mennawi, 2020; Rahman \& Sharma, 2020; Ullah et al., 2020).

While the results of the Intellectual Capital variable test show a regression coefficient of $t_{\text {count }}(-2.525)<t_{\text {table }}(1.989)$ with a significance level of 0.140 greater than $5 \%$ or $(0.140)>\alpha(0.05)$. The test results indicate that $\mathrm{H}_{0}$ is accepted and $\mathrm{H}_{1}$ is rejected. Therefore, it can be concluded that Intellectual Capital has a negative and insignificant effect on Financial

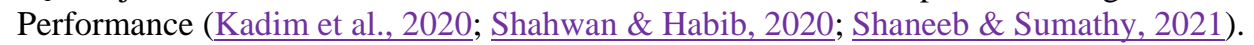


Table 6: Summary of Research Results

\begin{tabular}{|c|c|c|c|c|}
\hline No & Hypothesis & Result (Meaning) & P-Value & Conclusion \\
\hline 1 & $\begin{array}{l}\text { Hypothesis } 1 \\
\text { Corporate Social Responsibility } \\
\text { (CSR) has a positive effect on } \\
\text { Financial Performance (FP) }\end{array}$ & $\begin{array}{l}\text { Coef.: } 2,484 \\
\text { (positive effect) }\end{array}$ & $\begin{array}{l}\mathrm{P}=0,015 \text { or } \mathrm{P}< \\
0,05 \\
\text { (significant) }\end{array}$ & $\begin{array}{l}\text { Proven } \\
\text { Hypothesis }\end{array}$ \\
\hline 2 & $\begin{array}{l}\text { Hypothesis } 2 \\
\text { Leverage (LEV) has a positive effect } \\
\text { on Financial Performance (FP) }\end{array}$ & $\begin{array}{l}\text { Coef.: }-0,428 \\
\text { (negative effect) }\end{array}$ & $\begin{array}{l}\mathrm{P}=0,670 \text { or } \mathrm{P}> \\
0,05 \\
\text { (not significant) }\end{array}$ & $\begin{array}{l}\text { Hypothesis } \\
\text { Rejected } \\
\text { (Not proven) }\end{array}$ \\
\hline 3 & $\begin{array}{l}\text { Hypothesis } 3 \\
\text { Intellectual Capital (IC) has a } \\
\text { positive effect on Financial } \\
\text { Performance (FP) }\end{array}$ & $\begin{array}{l}\text { Coef.: }-2,525 \\
\text { (negative effect) }\end{array}$ & $\begin{array}{l}\mathrm{P}=0,140 \text { or } \mathrm{P}> \\
0,05 \\
\text { (not significant) }\end{array}$ & $\begin{array}{l}\text { Hypothesis } \\
\text { Rejected } \\
\text { (Not proven) }\end{array}$ \\
\hline
\end{tabular}

Source: The author's own study, 2021

\section{CONCLUSION AND RECOMMENDATIONS}

Based on the results of the discussion above, this study concludes at least three things: first, the Influence of Corporate Social Responsibility on Financial Performance. The first hypothesis $\left(\mathrm{H}_{1}\right)$ states that the Corporate Social Responsibility variable has a positive effect on Financial Performance. This statement can be interpreted to improve and introduce a good company image to the public; Corporate Social Responsibility (CSR) activities carried out by companies can increase exposure or popularity in the community. In addition, this strategy can also affect profitability. Therefore, the first hypothesis $\left(\mathrm{H}_{1}\right)$ is declared acceptable or has a positive effect on Financial Performance. Second, the hypothesis $\left(\mathrm{H}_{2}\right)$, which states that Leverage has a significant positive effect on Financial Performance, is rejected. This means that the Leverage variable has no effect on Financial Performance. In other words, the size of the company's burden on creditors has no influence on the acquisition of assets owned by the company. Therefore, the use of high debt has no effect on the company's sustainability in improving the company's financial performance. Likewise in the third hypothesis $\left(\mathrm{H}_{3}\right)$ which states that the Intellectual Capital variable has no effect on Financial Performance. This means that the use of intangible assets in companies that are not utilized effectively and efficiently or are not managed optimally have no effect on increasing results on the company's financial performance. Therefore, the third hypothesis statement $\left(\mathrm{H}_{3}\right)$ is rejected.

This study shows that the literal financial statements with the company's financial performance. In other words, the more disclosure of corporate social responsibility activities in the company's annual report, the more it will improve the financial performance of banking companies. On the other hand, not entirely the burden borne by the company resulted from debts to creditors. Therefore, the amount of assets owned by the company is not generated entirely from debt so that there is no dependence of a company on creditors.

The results of this study can be used for financial practitioners, especially in the banking industry, to determine the effect of corporate social responsibility, leverage, and intellectual capital on financial performance. Therefore, banking companies can make decisions based on the priority scale on the most influential variables. In addition, this research can also be a reference for academics and researchers who are interested in the issue of financial performance.

\section{LIMITATIONS AND STUDY FORWARD}

This study has several limitations, especially in terms of the sample, time period, and research approach used. Therefore, this study hopes for further research by developing these three aspects to obtain a more comprehensive picture of the condition of the company's financial performance. In addition, other research variables that affect financial performance, such as ROE, DER, Internal Audit, Auditor Quality, and Earnings Management, need to be considered for analysis.

\section{ACKNOWLEDGEMENT}

We would like to give Universitas Nasional and L'universite de Angers the highest appreciation for all the support, both administratively and financially. Likewise, for colleagues who have provided extraordinary feedback on this research.

\section{AUTHORS' CONTRIBUTION}

This research was performed in collaboration between all authors. Subiyanto and Awaludin arranged the review, performed the analysis, and construct the preliminary manuscript. Demolingo, Ifani, and Wiweka supervised the analyses and the literature review. All authors acknowledged the latest manuscript.

\section{REFERENCES}

1. Afolabi, A., Olabisi, J., Kajola, S. O., \& Asaolu, T. O. (2019). Does leverage affect the financial performance of Nigerian firms? Journal of Economics \& Management, 37, 5-22. https://doi.org/10.22367/jem.2019.37.01 
2. Awaysheh, A., Heron, R. A., Perry, T., \& Wilson, J. I. (2020). On the relation between corporate social responsibility and financial performance. Strategic Management Journal, 41(6), 965-987. https://doi.org/10.100 2/smj.3122

3. Bollen, L., Vergauwen, P., \& Schnieders, S. (2005). Linking intellectual capital and intellectual property to company performance. Management Decision, 43(9), 161-1185. https://doi.org/10.1108/00251740510626254

4. Calza, F., Dezi, L., Schiavone, F., \& Simoni, M. (2014). The intellectual capital of business incubators. Journal of Intellectual Capital, 15(4), 597-610. https://doi.org/10.1108/JIC-07-2014-0086

5. Chen, H., \& Wang, X. (2011). Corporate social responsibility and corporate financial performance in China: An empirical research from Chinese firms. Corporate Governance: The International Journal of Business in Society, 11(4), 361-370. https://doi.org/10.1108/14720701111159217

6. Chowdhury, L. A. M., Rana, T., \& Azim, M. I. (2019). Intellectual capital efficiency and organisational performance: In the context of the pharmaceutical industry in Bangladesh, Journal of Intellectual Capital, 20(6), 784-806. https://doi.org/10.1108/JIC-10-2018-0171

7. Deegan, C. (2014). An overview of legitimacy theory as applied within the social and environmental accounting literature. Sustainability Accounting and Accountability, 2, 248-272.

8. Elena, N. I. (2012). Company performance measurement and reporting methods. Annals of Faculty of Economics, 1(2), 700-707.

9. Elkington, J. (2013). Enter the triple bottom line (pp. 23-38). Routledge.

10. Erica, D. (2018). Analisa Rasio Laporan Keuangan Untuk Menilai Kinerja Perusahaan PT Kino Indonesia Tbk (Ratio Analysis of Financial Statements to Assess Company Performance PT Kino Indonesia Tbk). Jurnal Ecodemica, 2(1), 12-20. https://doi.org/10.32493/skt.v1i3.1088

11. Fuadah, L. L., Arisman, A., Wardani, R. S., \& Yunita, A. (2019). Corporate Social Responsibility Mediates Corporate Governance Index and Financial Performance in Indonesia. Academy of Accounting and Financial Studies Journal, 23, 1-8.

12. Ghozali, I. (2011). Analisis Multivariate dengan program IBM SPSS 19 (Multivariate Analysis with IBM SPSS 19 program). Semarang: Badan Penerbit Fakultas Ekonomi Universitas Diponegoro.

13. Gray, R. (2010). Is accounting for sustainability actually accounting for sustainability... and how would we know? An exploration of narratives of organisations and the planet. Accounting, Organizations and Society, 35(1), 47-62. https://doi.org/10.1016/j.aos.2009.04.006

14. Janošević, S., Dženopoljac, V., \& Bontis, N. (2013). Intellectual capital and financial performance in Serbia. Knowledge and Process Management, 20(1), 1-11. https://doi.org/10.1002/kpm.1404

15. Javed, M., Rashid, M. A., Hussain, G., \& Ali, H. Y. (2020). The effects of corporate social responsibility on corporate reputation and firm financial performance: Moderating role of responsible leadership. Corporate Social Responsibility and Environmental Management, 27(3), 1395-1409. https://doi.org/10.1002/csr.1892

16. Jensen, M. C., \& Meckling, W. H. (1976). Theory of the firm: Managerial behavior, agency costs and ownership structure. Journal of Financial Economics, 3(4), 305-360. https://doi.org/10.1016/0304405X(76)90026-X

17. Joshi, M., Cahill, D., Sidhu, J., \& Kansal, M. (2013). Intellectual capital and financial performance: An evaluation of the Australian financial sector. Journal of Intellectual Capital, 14(2). https://doi.org/10.110 $\underline{8} / 14691931311323887$

18. Kadim, A., Sunardi, N., \& Husain, T. (2020). The modeling firm's value based on financial ratios, intellectual capital and dividend policy. Accounting, 6(5), 859-870. https://doi.org/10.5267/j.ac.2020.5.008

19. Kianto, A., Andreeva, T., \& Pavlov, Y. (2013). The impact of intellectual capital management on company competitiveness and financial performance. Knowledge Management Research \& Practice, 11(2), 112-122. https://doi.org/10.1057/kmrp.2013.9

20. Laksana, A. E., \& Sudarno, S. (2013). Hubungan intellectual capital, kinerja keuangan dan nilai perusahaan saat IPO (Relationship between intellectual capital, financial performance and firm value at IPO). [PhD Thesis]. Fakultas Ekonomika dan Bisnis.

21. Lin, C.-H., Yang, H.-L., \& Liou, D.-Y. (2009). The impact of corporate social responsibility on financial performance: Evidence from business in Taiwan. Technology in Society, 31(1), 56-63. https://doi.org/10.1016/j.techsoc.2008.10.004

22. Liu, Y., Saleem, S., Shabbir, R., Shabbir, M. S., Irshad, A., \& Khan, S. (2021). The relationship between corporate social responsibility and financial performance: A moderate role of fintech technology. Environmental Science and Pollution Research, 28(16), 20174-20187. https://doi.org/10.1007/s113 56-020-11822-9

23. Magness, V. (2006). Strategic posture, financial performance and environmental disclosure. Accounting, Auditing \& Accountability Journal, 19(4), 540-563. https://doi.org/10.1108/09513570610679128

24. Maith, H. A. (2013). Analisis Laporan Keuangan dalam Mengukur Kinerja Keuangan pada PT. Hanjaya Mandala Sampoerna Tbk (Financial Statement Analysis in Measuring Financial Performance at PT. Hanjaya Mandala Sampoerna Tbk). Jurnal EMBA: Jurnal Riset Ekonomi, Manajemen, Bisnis Dan Akuntansi, 1(3). 
25. Mennawi, A. N. A. (2020). The Impact of Liquidity, Credit, and Financial Leverage Risks on Financial Performance of Islamic Banks: A Case of Sudanese Banking Sector. Risk and Financial Management, 2(2), 5972. https://doi.org/10.30560/rfm.v2n2p59

26. Mojambo, G. A., Tulung, J. E., \& Saerang, R. T. (2020). The Influence of Top Management Team (TMT) Characteristics Toward Indonesian Banks Financial Performance During The Digital Era (2014-2018). JMBI UNSRAT (Jurnal Ilmiah Manajemen Bisnis Dan Inovasi Universitas Sam Ratulangi), 7(1), 1-20. https://doi.org/10.35794/jmbi.v7i1.27619

27. Moneva, J. M., Rivera-Lirio, J. M., \& Muñoz-Torres, M. J. (2007). The corporate stakeholder commitment and social and financial performance. Industrial Management \& Data Systems, 107(1), 84-102. https://doi.org/10. $1108 / 02635570710719070$

28. Muna, N., \& Prastiwi, A. (2014). Pengaruh intellectual capital terhadap return saham melalui kinerja keuangan pada perusahaan real estate dan properti yang terdaftar di Bursa Efek Indonesia (BEI) tahun 2010-2012 (The influence of intellectual capital on stock returns through financial performance in real estate and property companies listed on the Indonesia Stock Exchange (IDX) in 2010-2012). [PhD Thesis]. Fakultas Ekonomika dan Bisnis.

29. Mustafa, C. C., \& Handayani, N. (2014). Pengaruh Pengungkapan Corporate Social Responsibility Terhadap Kinerja Keuangan Perusahaan Manufaktur (The Effect of Corporate Social Responsibility Disclosure on the Financial Performance of Manufacturing Companies). Jurnal Ilmu \& Riset Akuntansi, 3(6).

30. Natalylova, K. (2013). Pengaruh corporate governance terhadap corporate social responsibility dan kinerja perusahaan yang mendapatkan Indonesia suistainabilty reporting awards (The influence of corporate governance on corporate social responsibility and the performance of companies that received the Indonesia Sustainability Reporting Awards). Media Bisnis, 5(3), 162-182.

31. Nopitasari, H., Tiorida, E., \& Sarah, I. S. (2017). Pengaruh Financial Leverage Terhadap Kinerja Keuangan (Studi Pada Perusahaan Properti dan Real Estate yang Terdaftar di Bursa Efek Indonesia Periode 2011-2015). (The Effect of Financial Leverage on Financial Performance (Study on Property and Real Estate Companies Listed on the Indonesia Stock Exchange 2011-2015 Period)). Jurnal Riset Bisnis Dan Investasi, 3(3), 45-56. https://doi.org/10.35697/jrbi.v3i3.944

32. Oktafianti, D. (2015). Pengaruh Kepemilikan Manajerial, Ukuran Perusahaan dan Kinerja Keuangan Terhadap Corporate Environmental Disclosure Sebagai Bentuk Tanggung Jawab Sosial dalam Laporan Tahunan (Studi pada Perusahaan Peserta Proper 2011-2013) [PhD Thesis]. UNIVERSITAS AIRLANGGA.

33. Partalidou, X., Zafeiriou, E., Giannarakis, G., \& Sariannidis, N. (2020). The effect of corporate social responsibility performance on financial performance: the case of food industry. Benchmarking: An International Journal, 27(10), 2701-2720. https://doi.org/10.1108/BIJ-11-2019-0501

34. Rabuisa, W. F., Runtu, T., \& Wokas, H. R. (2018). Analisis Laporan Keuangan Dalam Menilai Kinerja Keuangan Perusahaan Pada Bank Perkreditan Rakyat (Bpr) Dana Raya Manado (Financial Statement Analysis in Assessing the Company's Financial Performance at the Rural Bank (BPR) Dana Raya Manado). Going Concern: Jurnal Riset Akuntansi, 13(02), 325-333. https://doi.org/10.32400/gc.13.02.19518.2018

35. Rachmanda, M., Munthe, I. L. S., \& Ruwanti, S. (2016). Pengaruh Ukuran Perusahaan, Return on Asset, Debt to Equity Ratio, Opini Auditor, Dan Reputasi Kap Terhadap Audit Delay (The Effect of Company Size, Return on Asset, Debt to Equity Ratio, Auditor's Opinion, And Kap Reputation on Audit Delay).

36. Rahman, A., \& Sharma, R. B. (2020). Cash flows and financial performance in the industrial sector of Saudi Arabia: With special reference to Insurance and Manufacturing Sectors. Investment Management and Financial Innovations, 17(4), 76-84. https://doi.org/10.21511/imfi.17(4).2020.07

37. Rehman, S. S. F. U. (2013). Relationship between financial leverage and financial performance: Empirical evidence of listed sugar companies of Pakistan. Global Journal of Management and Business Research. Retrieved from https://journalofbusiness.org/index.php/GJMBR/article/view/1081

38. Rizal, M. (2017). Analisis Kinerja Keuangan PT. Garuda Indonesia Tbk. (Financial Performance Analysis of PT. Garuda Indonesia Tbk). Jurnal Serambi Dan Bisnis, 4(1).

39. Safira, Z., \& Riduwan, A. (2015). Pengaruh Corporate Social Responsibility dan kinerja keuangan pada harga saham (Effect of Corporate Social Responsibility and financial performance on stock prices). Jurnal Ilmu Dan Riset Akuntansi (JIRA), 4(6).

40. Sarwoko, I., \& Agoes, S. (2014). An empirical analysis of auditor's industry specialization, auditor's independence and audit procedures on audit quality: Evidence from Indonesia. Procedia-Social and Behavioral Sciences, 164, 271-281. https://doi.org/10.1016/j.sbspro.2014.11.077

41. Sayekti, Y., \& Wondabio, L. S. (2007). Pengaruh CSR disclosure terhadap earning response coefficient (Effect of CSR disclosure on earning response coefficient). Simposium Nasional Akuntansi X, 26.

42. Schuler, R. S., \& Jackson, S. E. (1987). Linking competitive strategies with human resource management practices. Academy of Management Perspectives, 1(3), 207-219. https://doi.org/10.5465/ame.1987.4275740

43. Shahwan, T. M., \& Habib, A. M. (2020). Does the efficiency of corporate governance and intellectual capital affect a firm's financial distress? Evidence from Egypt. Journal of Intellectual Capital, 21(3), 403-430. https://doi.org/10.1108/JC-06-2019-0143 
44. Shaneeb, P., \& Sumathy, M. (2021). Impact of Intellectual Capital on Financial Performance in Indian Textile Industries. Academy of Accounting and Financial Studies Journal, 25(4), 1-14.

45. Staniewski, M. W., Szopiński, T., \& Awruk, K. (2016). Setting up a business and funding sources. Journal of Business Research, 69(6), 2108-2112. https://doi.org/10.1016/j.jbusres.2015.12.016

46. Strömsten, T., \& Waluszewski, A. (2012). Governance and resource interaction in networks. The role of venture capital in a biotech start-up. Journal of Business Research, 65(2), 232-244. https://doi.org/10.1016/j.j busres.2010.11.030

47. Subiyanto, B., \& Ghozali, I. (2021). Empirical Study of the Relationship between Managerial Accounting Discretion and Innate Factors with the Quality of Financial Reporting. DEGRES, 20(1), 59-73.

48. Sudana, I. M. (2011). Manajemen Keuangan Perusahaan Teori \& Praktik (Corporate Financial Management: Theory \& Practice). Jakarta: Erlangga

49. Sugiyono, P. (2016). Metode Penelitian Manajemen(Pendekatan Kuantitatif, Kualitatif, Kombinasi (Mixed Methods), Penelitian Tindakan (Action Research, dan Penelitian Evaluasi) (Management Research Methods (Quantitative, Qualitative, Combination Approaches (Mixed Methods), Action Research (Action Research, and Evaluation Research)). Bandung: Alfabeta Cv.

50. Sunarsih, N.M. \& Mendra, N. P. Y. (2012). Pengaruh Modal Intelektual Terhadap Nilai Perusahaan Dengan Kinerja Keuangan Sebagai Variabel Intervening Pada Perusahaan Yang Terdaftar Di Bursa Efek Indonesia. Makalah Disampaikan dalam Simposium Nasional Akuntansi XV. Banjarmasin: 20-23 September. (The Effect of Intellectual Capital on Firm Value with Financial Performance as an Intervening Variable in Companies Listed on the Indonesia Stock Exchange. Paper Presented in the XV National Accounting Symposium. Banjarmasin: 20-23 September).

51. Susanti, N., Widajatun, V. W., Aji, M. B., \& Nugraha, N. M. (2020). Implications of Intellectual Capital Financial Performance and Corporate Values. International Journal of Psychosocial Rehabilitation, 24(07).

52. Tedjo, I. (n.d.). Fahmi, Irham Analisis Laporan Keuangan. Bandung: Alfabeta. Fama, E. (Financial Statement Analysis.)

53. Tsoutsoura, M. (2004). Corporate social responsibility and financial performance. UC Berkeley: Center for Responsible Business. Retrieved from https://escholarship.org/uc/item/111799p2

54. Turcsanyi, J., \& Sisaye, S. (2013). Corporate social responsibility and its link to financial performance: Application to Johnson \& Johnson, a pharmaceutical company. World Journal of Science, Technology and Sustainable Development, 10(1), 4-18. https://doi.org/10.1108/20425941311313065

55. Ullah, A., Pinglu, C., Ullah, S., Zaman, M., \& Hashmi, S. H. (2020). The nexus between capital structure, firmspecific factors, macroeconomic factors and financial performance in the textile sector of Pakistan. Heliyon, 6(8), e04741. https://doi.org/10.1016/j.heliyon.2020.e04741

56. Xu, J., \& Liu, F. (2020). The impact of intellectual capital on firm performance: A modified and extended VAIC model. Journal of Competitiveness, 12(1), 161. https://doi.org/10.7441/joc.2010.01.10

57. Zeghal, D., \& Maaloul, A. (2010). Analysing value added as an indicator of intellectual capital and its consequences on company performance. Journal of Intellectual Capital, 11(1), 39-60. https://doi.org/10. $\underline{1108 / 14691931011013325}$ 